\title{
Growth promotion of transplanted rice plant by bioagents effective against bacterial leaf blight disease of rice under glasshouse conditions
}

\author{
Gokil Prasad Gangwar* and A. P. Sinha \\ (Uttarakhand) INDIA \\ *Corresponding author. E-mail: gokil_prasad@rediffmail.com \\ Received: February 8, 2014; Revised received: May 18, 2014; Accepted: May 27, 2014
}

Department of Plant Pathology, G. B. Pant University of Agriculture and Technology, Pantnagar, 263145

\begin{abstract}
The experiment was conducted to evaluate growth promotion of transplanted rice by fungal and bacterial bioagents effective against bacterial leaf blight of rice, under glasshouse conditions. Bioagent formulations (PBA -1, PBA -2, FLP 88, Pf 83, Isolate 40 and $T$. harzianum) were applied as seed treatment, seedling root dip and foliar spray and compared with chemical treatment and untreated check. All bioagent formulations were significantly effective in increasing number of tillers per hill, root length, total phenolic content in rice leaves, fresh and dry root weight, fresh and dry shoot weight, flag leaf area, grain yield and 1000 grain weight over check. Present study revealed that potential fungal and bacterial bioagents effective against bacterial leaf blight disease of rice, exhibited plant growth promoting activities and resulted 22.38 to $32.08 \%$ increase in grain yield over untreated check, even if there is no disease.
\end{abstract}

Keywords: Foliar application, Growth promotion, Pseudomonas spp., Rice, Seedling root dip, Trichoderma harzianum

\section{INTRODUCTION}

Fungal and bacterial bioagents are reported to induce the growth of various crop plants (Singh and Sinha, 2008; Singh et al., 2012). These responses may be due to: (i) Suppression of deleterious root micro-flora including those not causing obvious disease, (ii) Production of growth stimulating factors (hormones or growth factors) and /or (iii) Increased nutrient uptake takes through solubilization and sequestration of nutrients and/or enhanced root growth. Enhanced root development is also helpful in tolerating the biotic and abiotic stresses by the plants. Spore/cell suspension as well as dry powder has been used to coat the seeds with potential antagonists (Chao et al., 1986; Mukhopadhyay et al., 1992). For commercial purpose, dry powders of antagonists are used @ 3 to 8 g powder per $\mathrm{kg}$ seed based on seed size and formulations of antagonists (Mukhopadhyay, et al., 1992; Mukherjee and Mukhopadhyay, 1995). A large number of seed, seedling, root, stem, foliar and panicle diseases have been suppressed by seed treatment with antagonists. Mukhopadhyay (1996) reported increased growth of several crop plants following seed treatment with $T$. harzianum and $T$. virens. Antagonists also stimulate plant growth, even if there is no disease, which results in better yield (Mishra and Sinha, 2000). Different fungal and bacterial bioagents were found effective in promoting growth of rice seedling under laboratory and in nursery raised under glasshouse (Gangwar, 2013c). In the present study, experiment was conducted to evaluate plant growth promoting activities of potential fungal and bacterial bioagents (effective against bacterial leaf blight of rice) on transplanted rice under glasshouse conditions.

\section{MATERIALS AND METHODS}

Two Pseudomonas spp. isolates (Pf 83 and FLP 88), two Trichoderma spp. isolates (isolate 40 and Trichoderma harzianum) and two commercial formulations viz. PBA-1 (T. harzianum PBAT-43) and PBA-2 (P. fluorescens PBAP-27) were tested for growth promoting activity on transplanted rice. These bioagents were effective against Xanthomonas oryzae pv. oryzae causing bacterial leaf blight in rice, under laboratory (Gangwar and Sinha, 2010a,b), glasshouse (Gangwar and Sinha, 2012a,b) and field conditions (Gangwar, 2012; Gangwar, 2013a,b). These bioagents were also effective in promoting growth of rice seedling under laboratory and glasshouse conditions (Gangwar, 2013c). In the present study, experiment was carried out at glasshouses of Department of Plant Pathology to evaluate plant growth promoting activities of these fungal and bioagents on transplanted rice plant and on grain yield. The experiment was conducted, India.

Mass multiplication of fungal and bacterial bioagents and preparation of formulations: Two commercial formulation of T. harzianum (PBA-1) and $P$. fluorescens (PBA-2) obtained from Bio-control 
Laboratory, Department of Plant Pathology and four formulations of $P$. fluorescens ( $P f 83$, rice leaf isolate), fluorescent pseudomonad (FLP 88, rice leaf isolate), $T$. harzianum (rice leaf isolate), Trichoderma spp. (isolate 40 , isolated from rice field soil) were used in the present study. Trichoderma spp. was mass multiplied on barnyard millet: Echinocloa frumentacae (local name: Jhangora) grains. Jhangora grains colonized by Trichoderma were air dried in open shade and ground with the help of Willy Mill to get fine powder. This powder was passed through 50 and 80 mesh sieves, simultaneously to obtain spore powder. Fluorescent pseudomonads were multiplied on King's B broth. The isolates were used to inoculate the flask containing 100 $\mathrm{ml} \mathrm{KB}$ broth and incubated on incubator shaker at 150 $\mathrm{rpm}$ for $48 \mathrm{~h}$ at $25 \pm 2{ }^{0} \mathrm{C}$. Bacterial suspension was then mixed directly with sterilized talc powder (@ 1.2, v/w), air dried and mixed well under sterile conditions. The formulations of fungal and bacterial bioagents were prepared by diluting bacterial cell powder or spore powder with talcum powder (mesh $=350$ with $95 \%$ whiteness) and 1\% carboxyl methyl cellulose (CMC) to get desired concentration $\left(10^{6} \mathrm{cfu} / \mathrm{g}\right)$ of bioagents in the formulation.

Seed treatment with bioagent formulations and chemical for raising nursery: The experiment was carried out using susceptible rice cultivar Jaya. Nursery was raised in separate pots in the glasshouse. Bioagent formulations $\left(10^{6} \mathrm{cfu} / \mathrm{g}\right)$ were applied as seed treatment (ST) at the rate of $10 \mathrm{~g} / \mathrm{kg}$ seed. For chemical treatment seeds were treated with Emisan and streptocycline $(0.76 \mathrm{~g}$ Emisan $+0.18 \mathrm{~g}$ Streptocycline $/ \mathrm{Kg}$ seeds). Treated seeds were soaked in tap water for $12 \mathrm{~h}$. For untreated check, seeds were soaked in sterilized water. Plastic pots were filled $3 / 4$ by height with natural field soil and fertilized with NPK (@ 120:60:40 kg/ha). Pots were arranged in Randomized Block Design and irrigated for puddling. After puddling, 1000 rice seeds treated with bioagent formulations, chemical and sterilized water was sown in separate pots to raise nursery.

Application of bioagent formulations and transplantation of rice seedlings: The experiment was conducted under glasshouse conditions. Plastic pots were filled $3 / 4$ by height with natural field soil and fertilized with NPK (@ 120:60:40 kg/ha). Pots were irrigated for puddling. After puddling, 21 days old seedlings were transplanted in each pot and two seedling / pot were maintained. Bioagent formulations and chemical treatment $(0.76 \mathrm{~g}$ Emisan $+0.18 \mathrm{~g}$ streptocycline /liter water) were applied as seedling root dip (SD). Roots of rice seedlings were soaked overnight in the solution of different bioagents and chemical. For untreated check sterilized water was used for soaking roots of rice seedlings. Pots were arranged in Randomized Block Design. Regular watering was done by using tape water. Six replications were maintained for each treatment. Three replications of each treatment were uprooted after 40 days after transplanting (DAT) for recording data on number tillers per hill, total phenolic content in leaves, root and shoot length, fresh root and shoot weight, dry root and shoot weight. Other three replications of each treatment were maintained for further observations. After 40 DAT, bioagent formulations and chemical treatment $(0.03 \mathrm{~g}$ streptocycline $+1 \mathrm{~g}$ copper oxychloride /liter water) were applied as foliar spray (FS) and sterilized water used for untreated check. After panicle emergence flag leaf area was recorded. After harvesting, grain yield and 1000 grain weight were recorded.

Measurement of total phenolic content in rice leaves: Different bioagents were evaluated for their ability to induce accumulation of total phenolics in rice leaves. Phenols were estimated by the procedure described by Sadasivam and Manickam (1997).

Reagents: (1) Methanol, 80\% (2) Folin-Ciocalteau reagent - commercially available reagent was diluted with distilled water in 1:1 ratio and used. (3) Sodium carbonate, $20 \%$ - prepared by dissolving 20 g sodium carbonate in $100 \mathrm{ml}$ distilled water.

Extraction of phenols: $1 \mathrm{~g}$ leaf tissue was grinded in 5 $\mathrm{ml} 80 \%$ methanol. The extract was agitated at $70^{\circ} \mathrm{C}$ for 15 minutes. Now this methanolic extract was used for estimation of total phenols.

Procedure: To the $1 \mathrm{ml}$ sample (methanolic extract of rice leaves) $5 \mathrm{ml}$ distilled water was added to make the final volume $6 \mathrm{ml}$. To this $250 \mu$ l Folin's reagent was added and the mixture was incubated for $3 \mathrm{~min}$ at room temperature. After incubation, $1 \mathrm{ml} 20 \%$ sodium carbonate and $1 \mathrm{ml}$ distilled water were added and the solution was incubated for $1 \mathrm{hr}$ at room temperature. Absorbance was recorded at $725 \mathrm{~nm}$. The amount of total phenols was estimated from the standard curve for tannic acid and expressed as $\mu \mathrm{g}$ phenol $\mathrm{g}^{-1}$ fresh leaf weight.

Statistical analysis: Statistical analysis of the data obtained from experiment was done using appropriate programme as per the requirement of the experiment. The critical difference (CD) was calculated at 5\% level of significance for comparison of difference between the means of different treatments.

\section{RESULTS}

Effect of bioagent formulations (applied as ST + SD) on number of tillers per hill, total phenolic content in leaves, root and shoot length of rice plant 40 DAT: All bioagent formulations and chemical treatment was significantly effective ( 24.33 to 28.33 ) in increasing average numbers of tillers per hill over check (14.00) (Table 1). Maximum increase (102.38\%) in number of tillers per hill was obtained by Pf 83 which is followed by PBA-2 (100.00\%) and $T$. harzianum (97.61\%). All bioagent formulations were significantly effective in increasing total phenolic content in rice leaves over check. Total phenolic content in rice leaves increased by chemical treatment 
Table 1. Effect of bioagent formulations (applied as seed treatment + seedling root dip) on number of tillers per hill, total phenolic content in leaves, shoot length and root length after 40 days of transplanting.

\begin{tabular}{lcccc}
\hline $\begin{array}{l}\text { Treat- } \\
\text { ments }\end{array}$ & $\begin{array}{c}\text { Average } \\
\text { number } \\
\text { of till- } \\
\text { ers/hill }\end{array}$ & $\begin{array}{c}\text { Total } \\
\text { phenolic } \\
\text { content } \\
(\boldsymbol{\mu g} / \mathbf{g})\end{array}$ & $\begin{array}{c}\text { Average } \\
\text { root } \\
\text { length } \\
\text { (cm) }\end{array}$ & $\begin{array}{c}\text { Average } \\
\text { shoot } \\
\text { length } \\
\text { (cm) }\end{array}$ \\
\hline Isolate & 24.33 & 275.00 & 23.33 & 90.00 \\
40 & 25.66 & 300.00 & 24.33 & 85.66 \\
PBA -1 & 27.66 & 308.33 & 24.66 & 85.00 \\
T. har- & 27.00 & 34.66 \\
zianum & 28.00 & 323.33 & 22.16 & 79.16 \\
PBA -2 & 24.66 & 278.33 & 22.66 & 82.66 \\
FLP 88 & 28.33 & 325.00 & 24.00 & 77.00 \\
Pf 83 & 28.33 \\
Chemi- & 20.33 & 188.33 & 20.33 & 70.66 \\
cal & 14.00 & 178.33 & 14.66 & $\mathrm{~ns}$ \\
Check & 3.23 & 31.00 & 5.75 & \\
CD at & $3 \%$ & & & \\
\hline
\end{tabular}

* Mean of six replications; ns = non-singnificant

was statistically equal to check. Maximum increase $(82.24 \%)$ in total phenolic content was exhibited by $P f$ 83 which is followed by PBA-2 $(81.31 \%)$ and $T$. harzianum (72.90\%). All the bioagent formulations were significantly effective $(22.16$ to $24.66 \mathrm{~cm})$ in increasing root length over check $(14.66 \mathrm{~cm})$. However, increase in root length by chemical treatment was statistically equal to check. Maximum increase $(68.25 \%)$ in root length was obtained with $T$. harzianum which is followed by PBA-1 (65.98\%) and Pf $83(63.71 \%)$. All treatments were non-significant (at $\mathrm{p}=0.05 \%$ ) in increasing shoot length over check. However, comparatively increased shoot length was exhibited by all the bioagents $(74.66$ to $90.00 \mathrm{~cm}$ ) as compared to check $(70.66 \mathrm{~cm})$.

Effect of bioagent formulations (applied as ST + SD) on fresh and dry root weight, fresh and dry shoot weight of rice plant 40 DAT: Data presented in table 2 , revealed that all bioagents were significantly effective in increasing fresh and dry root weight over check. Increase in fresh and dry root weight exhibited by chemical treatment was statistically equal to check. Maximum increase (185.72\%) in fresh root weight was exhibited by $T$. harzianum which was followed by $P f$ $83(183.98 \%)$ and PBA-2 (146.64 \%). Maximum increase $(203.44 \%)$ in dry root weight was shown by T. harzianum. Pf 83 and PBA-2 was next in order to increasing dry root weight by 200.86 and $163.87 \%$, respectively. Bioagent formulations viz. PBA-1 (3.99 g), T. harzianum (4.70 g), PBA-2 (4.09 g) and Pf 83 $(4.66 \mathrm{~g})$ exhibited significantly increased average dry root weight over chemical treatment $(2.15 \mathrm{~g})$. Significantly increased fresh and dry shoot weight over check was exhibited by all bioagent formulations (Table 2). Chemical treatment was at par with check in
Table 2. Effect of bioagent formulations (applied as seed treatment + seedling root dip) on fresh and dry root weight, fresh and dry shoot weight after 40 days of transplanting.

\begin{tabular}{|c|c|c|c|c|}
\hline $\begin{array}{l}\text { Treat- } \\
\text { ments }\end{array}$ & $\begin{array}{l}\text { Average } \\
\text { fresh } \\
\text { root } \\
\text { weight } \\
\text { (g) }\end{array}$ & $\begin{array}{c}\text { Average } \\
\text { dry } \\
\text { root } \\
\text { weight } \\
\text { (g) }\end{array}$ & $\begin{array}{l}\text { Average } \\
\text { fresh } \\
\text { shoot } \\
\text { weight } \\
\text { (g) }\end{array}$ & $\begin{array}{l}\text { Aver- } \\
\text { age dry } \\
\text { shoot } \\
\text { weight } \\
\text { (g) }\end{array}$ \\
\hline $\begin{array}{l}\text { Isolate } \\
40\end{array}$ & 31.89 & 3.25 & 78.73 & 8.59 \\
\hline PBA -1 & 40.67 & 3.99 & 79.36 & 8.06 \\
\hline $\begin{array}{l}\text { T. har- } \\
\text { zianum }\end{array}$ & 47.23 & 4.70 & 82.71 & 10.08 \\
\hline PBA -2 & 40.77 & 4.09 & 97.04 & 10.12 \\
\hline FLP 88 & 35.00 & 3.45 & 96.79 & 9.94 \\
\hline Pf 83 & 46.94 & 4.66 & 102.33 & 10.69 \\
\hline $\begin{array}{l}\text { Chemi- } \\
\text { cal }\end{array}$ & 20.03 & 2.15 & 55.90 & 5.75 \\
\hline Check & 16.53 & 1.55 & 40.76 & 3.68 \\
\hline $\begin{array}{l}\text { CD at } 5 \\
\%\end{array}$ & 14.78 & 1.57 & 28.15 & 3.77 \\
\hline
\end{tabular}

* Mean of six replications

increasing fresh and dry shoot weight. Maximum increase $(151.06 \%)$ in fresh shoot weight was recorded with $P f 83$ which is followed by PBA-2 (138.08\%) and FLP88 (137.46\%). Maximum increase in dry shoot weight was recorded with Pf 83 (190.48\%) which was followed by PBA-2 (175.18\%) and T. harzianum (173.91\%).

Effect of bioagent formulations (applied as ST + SD + FS) on flag leaf area, grain yield and 1000 grain weight: Significantly increased flag leaf area over check was exhibited by all bioagent formulations and chemical treatment (Table 3). Maximum increase $(21.31 \%)$ in flag leaf area was recorded with $T$. harzianum which was followed by PBA-1 (17.78\%) and PBA-2 (14.77\%). All bioagent formulations and chemical treatment were significantly effective in increasing grain yield (49.37 to $58.71 \mathrm{~g}$ ) over check $(44.45 \mathrm{~g})$. All bioagent formulations exhibited significantly higher grain yield over chemical treatment. Maximum increase $(32.08 \%)$ in grain yield was exhibited by Pf 83 which was followed by $T$. harzianum (29.43\%) and PBA-2 (26.95\%). Significantly increased 1000 grain weight (24.35 to $26.24 \mathrm{~g})$ exhibited by all bioagent formulations. Chemical treatment was at par with check in increasing 1000 grain weight. Maximum increase $(24.78 \%)$ in 1000 grain weight was exhibited by $T$. harzianum which was followed by Pf $83(22.25 \%)$ and PBA-2 $(21.85 \%)$.

\section{DISCUSSION}

In present investigation, bioagent formulations were significantly effective (at $\mathrm{p}=0.05 \%$ ) in increasing number of tillers per hill, root length, total phenolic content in rice leaves, fresh and dry root weight, fresh 
Table 3. Effect of bioagent formulations (applied as seed treatment + seedling root dip + foliar spray) on number of tillers/hill, Flag leaf area, grain yield and 1000 grain weight.

\begin{tabular}{lccc}
\hline $\begin{array}{l}\text { Treat- } \\
\text { ments }\end{array}$ & $\begin{array}{c}\text { Average } \\
\text { flag leaf } \\
\text { area }\left(\mathbf{c m}^{\mathbf{2}}\right)\end{array}$ & $\begin{array}{c}\text { Average } \\
\text { grain } \\
\text { yield (g) }\end{array}$ & $\begin{array}{c}\text { Average } \\
\text { 1000 grain } \\
\text { weight }(\mathbf{g})\end{array}$ \\
\hline Isolate 40 & 64.78 & 55.55 & 24.95 \\
PBA -1 & 66.58 & 55.22 & 25.54 \\
T. har- & 68.58 & 57.53 & 26.24 \\
zianum & & 56.43 & 25.62 \\
PBA - & 64.88 & 54.40 & 24.35 \\
FLP 88 & 64.00 & 58.71 & 25.71 \\
Pf 83 & 64.19 & 49.37 & 21.56 \\
Chemical & 61.17 & 44.45 & 21.03 \\
Check & 56.53 & 2.79 & 0.84 \\
CD at 5 \% & 3.46 & & \\
\hline
\end{tabular}

* Mean of three replications

and dry shoot weight, flag leaf area, grain yield and 1000 grain weight over check. Similarly, Trichoderma preparations have been reported to increase emergence and vigour of rice (Mishra and Sinha, 2000). However, chemical treatment was also effective in increasing flag leaf area and grain yield over check in the present study. Chemical treatment may inhibit the growth and/ or activities of detrimental microorganisms which may result in significantly enhanced growth and vigour of rice plant, as compared to check. Seed treatment and seedling root dip with bioagents also stimulated root length, fresh and dry root and shoot weight in the present study. Application of antagonists resulted in significant increase in root length of rice (Mishra and Sinha, 1998; Manmeet and Thind 2002). Dubey (1995) reported a significant increase in root and shoot length, fresh and dry weight and yield of cultivated crops due to seed bacterization with fluorescent pseudomonads. Increased fresh and dry weight of shoot, roots and nodules of broad bean was also reported by Yehia et al., 1985 when seeds were coated with $T$. viride. This may be because of production of growth stimulating factors by the bioagents (Windham et al., 1986; Schipper et al., 1987).

In most of cases, results showed that the effect of bioagents on growth and vigour of rice plant was significantly higher (at $\mathrm{p}=0.05 \%$ ) than chemical treatment. This revealed superiority of bioagents over the chemical treatment. Kloepper et al. (1980) reported that $P$. flourecens and other plant growth promoting rhizobacteria enhance plant growth by showing antagonisms to potentially deleterious rhizoplane fungal and bacterial pathogens. The direct application of microorganism to seed or other plant part gives them a competitive advantage over pathogen that must compete for nutrients and sites for attachment prior to infection. Reports are on hand indicating that bacteria may promote plant growth by suppression of deleterious root micro flora indicating those not causing obvious disease (Baker, 1986) altered root growth because of $\mathrm{N}$ production (Baker and Scher,
1987; Voisard et al., 1989), normal effect on plant growth (Imam et al., 1977), HCN production (Rangeshwaran and Prasad, 2000), increased root exudation (Prikryl and Vancura, 1980) and induce host resistance (Kempe and Sequeria, 1983).

\section{Conclusion}

It was revealed from present study that bioagent formulations which were had potential for the management of bacterial leaf blight disease were also exhibited plant growth promoting activity on rice plant when applied as combination of seed treatment, seedling root dip and foliar application and resulted in significantly higher grain yield (49.37 to $58.71 \mathrm{~g}$ as compared to untreated check $44.45 \mathrm{~g}$ ), even if there is no disease. Results of present investigation should be verified under field conditions.

\section{REFERENCES}

Baker, R. (1986). Biological Control: An Overview. Can. J. Pl. Path., 8: 218-221.

Baker, R. and Scher, F.M. (1987). Enhancing the activity of biological control agents. In: (Chet, I. ed.) Innovative Approaches to Plant Disease Control. Wiley Intersci. New York, U.S.A. pp. 1-18.

Chao, W.L., Nelson, F.B., Harman, G.E. and Hoch, H.C. (1986). Colonization of the rhizosphere by biological control agents applied to seeds. Phytopathology, 76:60-65.

Dubey, S. C. (1995). Evaluation of fungal antagonistic against Thanatephorus cucumeris causing banded blight of rice. Paper presented at the first International symposium on Rhizoctonia, ISR'95 at Leeuwenhorst Congress Centrum Noordwijkerhout, Netherland. pp. 27-30.

Gangwar, G.P. (2013a). Efficacy of different isolates of fluorescent pseudomonads against bacterial leaf blight of rice. Afr. J. Agric. Res., 8(37): 4588-4591.

Gangwar, G.P. (2013b). Field efficacy of formulation of fungal bioagents against bacterial leaf blight of rice caused by Xanthomonas oryzae pv. oryzae (Uyeda and Ishiyama) Dowson. J. Appl. \& Nat. Sci., 5(2): 423-426.

Gangwar, G.P. (2013c). Growth promotion of rice seedling by fungal and bacterial bioagents effective against bacterial leaf blight of rice. J. Appl. \& Nat. Sci., 5(2): 430-434.

Gangwar, G. P. (2012). Efficacy of commercial formulations of bioagent against bacterial leaf blight of rice. Ann. Pl. Protec. Sci., 20(2): 389-391.

Gangwar, G.P. and Sinha, A.P. (2010a). Comparative antagonistic potential of Trichoderma spp. against Xanthomonas oryzae pv. oryzae. Ann. Pl. Protec. Sci., 18(2): 458-463.

Gangwar, G.P. and Sinha, A.P. (2010b). Evaluation of fluorescent pseudomonads against Xanthomonas oryzae pv. oryzae causing bacterial leaf blight of rice. Ann. Pl. Protec. Sci., 18(2): 532-534.

Gangwar, G.P. and Sinha, A.P. (2012a). Comparative antagonistic potential of fungal and bacterial bioagents against isolates of Xanthomonas oryzae pv. oryzae. Ann. Pl. Protec. Sci., 20(1): 154-159.

Gangwar, G.P. and Sinha, A.P. (2012b). Evaluation of 
Trichoderma spp. and fluorescent pseudomonads for the management of bacterial leaf blight of rice. Indian Phytopath.., 65(1): 89-91.

Imam, M.K., Badawy, F.H. and El-Hudairy, A. (1977). Response of tomato and two other vegetable crops to inoculation with Azotobacter. The Libyan J. Agric., 6: 156-167.

Kempe, J. and Sequeira, L. (1983). Biological control of bacterial wilt of potatoes, attempts to induce resistance by treating tubers with bacteria. Plant Dis., 67: 499-503.

Kloepper, J.W., Schroth, M.N. and Miller, T.D. (1980). Effects of rhizosphere colonization by plant growth promoting rhizobacteria on potato plant development and yield. Phytopathology, 70: 1078-1082.

Manmeet, M. and Thind, B.S. (2002). Management of bacterial blight of rice with bioagents. Plant Dis. Res., 17(1): 21-28.

Mishra, D.S. and Sinha, A.P. (2000). Plant growth-promoting activity of some fungal and bacterial agents on rice seed germination and seedling growth. Trop. Agric., 77:188-191.

Mishra, D.S. and Sinha, A.P. (1998). Plant growth promotion by some biocontrol agents. In: Fiftieth Annual Meeting of Indian Phytopathological Society and National Symposium on "Present Scenario in Diseases of Oilseeds and Pulses" held at Aurangabad, Maharastra, India. (Abstr.).

Mukherjee, P.K. and Mukhopadhyay, A.N. (1995). In situ mycoparasitism of Gliocladium virens on Rhizoctonia solani. Indian Phytopath., 48: 101-102.

Mukhopadhyay, A.N. (1996). Recent innovations in plant disease control by ecofriendly biopesticides. In Presidential address, Agriculture Science section, $83^{\text {th }}$ Indian Science Congress, Patiala India.
Mukhopadhyay, A.N., Shrestha, S.M. and Mukherjee, P.K. (1992). Biological seed treatments for control of soil borne plant pathogens. FAO Plant Prot. Bull., 40: 1-10.

Prikryl, Z. and Vancura, V. (1980). Root exudates of plants. IV wheat root exudation as dependent on growth concentration gradient of exudates and the presence of bacteria. Plant and Soil, 57: 69-83.

Rangeshwaran, R. and Prasad, R.D. (2000). Isolation and evaluation of rhizospheric bacteria for biological control of chickpea wilt pathogen. J. Biol. Control, 14: 9-15.

Sadasivam, S. and Manickam, A.M. (1997). Biochemical methods. New Age International Publishers, New Delhi.

Schipper, B., Baker, A.W. and Baker, P.A.H.M. (1987). Interactions of deleterious and beneficial rhizosphere micro-organisms and the effect of cropping practice. Ann. Rev. Phytopath., 25: 339-358.

Singh, D., Yadav, D.K., Sinha, S. and Upadhyay, B.K. (2012). Utilization of plant growth promoting Bacillus subtilis isolates for the management of bacterial wilt incidence in tomato caused by Ralestonia solanacearum race 1 biovar 3. Indian Phytopath., 65(1): 18-24.

Singh, R. and Sinha, A.P. (2008). Growth promoting activities of Pseudomonas fluorescens on rice seedlings. Indian Phytopath., 61(2): 264-267.

Voisard, C., Keel, C., Hars, D. and Defago, G. (1989). Cyanide production by Pseudomonas fluorescens helps suppress black root rot of tobacco under genotobiotic conditions. EMBO J., 8: 351-358.

Windham, M.T., Elad, Y. and Baker, R. (1986). A mechanism for increased plant growth induced by Trichoderma spp. Phytopathology, 76: 518-521.

Yehia, A.H., EI-Hassan, S.A., EI-Bahadli and A.H. (1985). Biological seed treatment to control Fusarium root rot of broad bean. Egyptian J. Phytopathol., 14, 59-66. 